\title{
Appreciative Learning for Immersive Reward System in Education Game Development
}

\author{
Hanny Haryanto \\ Informatics Department \\ Universitas Dian Nuswantoro \\ Semarang, Indonesia \\ hanny.haryanto@dsn.dinus.ac.id
}

\author{
Ardiawan Bagus Harisa \\ Informatics Department \\ Universitas Dian Nuswantoro \\ Semarang, Indonesia \\ ardiawanbagus@dsn.dinus.ac.id
}

\author{
Indra Gamayanto \\ Information System Department \\ Universitas Dian Nuswantoro \\ Semarang, Indonesia \\ indra.gamayanto@dsn.dinus.ac.id
}

\begin{abstract}
Game replay-ability is very important in serious game to maximize the understanding for the learning content. The replay-ability is the result from the gameplay experience. Games have the advantage of providing a fun experience, and immersion is a vital element in game design to produce the experience. However, the design of immersion in games is often not well conceptualized so that it does not produce the expected experience. This study uses Appreciative Learning based reward system, which focuses on positive things such as peak achievements, opportunities, exploration of potential and optimism for the future. The reward activity consists of four stages, namely Discovery, Dream, Design and Destiny. Reward personalization is done by regulating reward behavior using artificial intelligence which runs in all four stages. Appreciative Learning will be used to design immersive experiences consisting of sensory, imaginary, and challenge-based immersion, which are the three main elements of immersive games. Intelligent agent behavior is modeled using the Finite State Machine. This study produces an immersive reward design that is applied to the concept of Appreciative Learning in designing a serious game.
\end{abstract}

Keywords-appreciative learning; artificial intelligence; immersive; reward; serious game

\section{INTRODUCTION}

The use of educational games is seen as an effective solution in providing practical experiences of learning, which have advantages in fostering a positive attitude and enjoyment in participating in learning [1]. [2] use games for pre-school learning activities and formulate a pedagogic model. They reveal that certain game genres, such as Role-Playing Games also have significant cognitive content. Research conducted by [3] concluded that the use of games for learning can shape cooperative behavior, create learning motivation and provide practical experiences to students.

The advantage of games as a learning tool is that they can provide a pleasant practical experience so that it can increase understanding of the material [4]. The immersive factor is the main determinant of whether the experience a game provides. Immersive experiences are experiences where the player feels immersed in the game. According to [5], this experience is divided into three, namely sensory immersion, imaginative immersion and challenge-based immersion. Sensory immersion is a type of immersive experience related to the five senses, such as visuals and sounds. Imaginative immersion relates to imagination such as the world in games, characters, and stories. Challenge-based immersion deals with the challenges offered by the game. A good combination of these three experiences will result in immersive gaming [6]. Currently, research on immersive games is dominated by the sensory immersion aspect in the form of Virtual Reality as done by [7] who made games for airflow simulation, learning games about architecture and construction using Virtual Reality [8], and surgical simulation [9]. However, research in the imaginative and challenge-based immersion aspects is still minimal.

In strengthening the understanding of the material provided in educational games, the reward element is one of the most important parts of the game. Reward personalization is intended so that learners have different and unique experiences resulting in impressive memories [10]. Reward generally provides feedback in the form of evaluation and motivation for the actions taken. Games have several positive things, including: (1) Games can be used to improve brain and memory: Train problem solving and logic., Train hand and eye coordination, fine motor skills, and spatial abilities follow instructions and make plans., Think quickly, make analysis and decisions quickly, Train strategy and anticipation, strengthen memory and concentration, dare to take risks and train how to face challenges. (2) Introducing technology more attractively, (3) Increasing creativity, (4) Increasing self-confidence, (5) Increasing new knowledge, (6) Learning something in a fun way, (7) Increasing accuracy and accuracy.

Rewards aim to provide clues about what players have done and provide appreciation to accommodate achievements. Even though there are rewards, boredom and frustration can still occur if the rewards are too easy to predict [11]. One of the criteria for a good reward is dynamic, that is, it can change according to the achievement criteria of the player [12]. Research on dynamic reward has been carried out in previous studies [13] which discussed its general application in educational games. Then, a general framework for using dynamic rewards in educational games based on Appreciative Learning has also been implemented [14]. In determining dynamic rewards, it depends on the player's achievement criteria in the game or player actions during play. This measure can be used as input to determine dynamic reward [15]. [16] 
suggested the importance of game elements that can adapt dynamically in a learning environment. Then, [17] discusses personalization in educational games using artificial intelligence. Personalization using artificial intelligence was also carried out to make recommendations in a gamification system [18].

In a study conducted by [15] using the Finite State Machine to recognize the actions of players and followed by [13] who designed dynamic reward behavior using the Finite State Machine model. However, the focus of this research is only on reward personalization and is not based on the right concept so that the rewards that are developed are not well conceptualized which results in the reward system being random and monotonous.

This study will design an immersive reward system based on the concept of Appreciative Learning. Appreciative Learning, which is a learning concept that emphasizes positive things, such as achievement, opportunities, potential and optimism [19] will be used to shape and classify reward behavior, which is divided into four stages, namely Discovery, Dream, Design and Destiny.

\section{RESEARCH METHOD}

\section{A. Overview of the Game Reward Model}

Figure 1 shows the overview of the game reward model. Player action will change the condition of game environment, which contains education content. The education content will determine the design of game environment; however, the content will not be presented explicitly. The game potential for learning could be maximized when the play comes first, then learn after that [20]. Appreciative Learning is used to design the reward system. The reward system takes game environment as the input and using the intelligent agent to produce rewards for player. Finite state machine will control the behavior of intelligent agent.

\section{B. Appreciative Learning for Reward System}

Appreciative Learning is a concept derived from Appreciative Inquiry. This concept focuses on positive things as the basis of learning [21]. Appreciative Learning consists of four stages of activity, as shown in Figure 2.

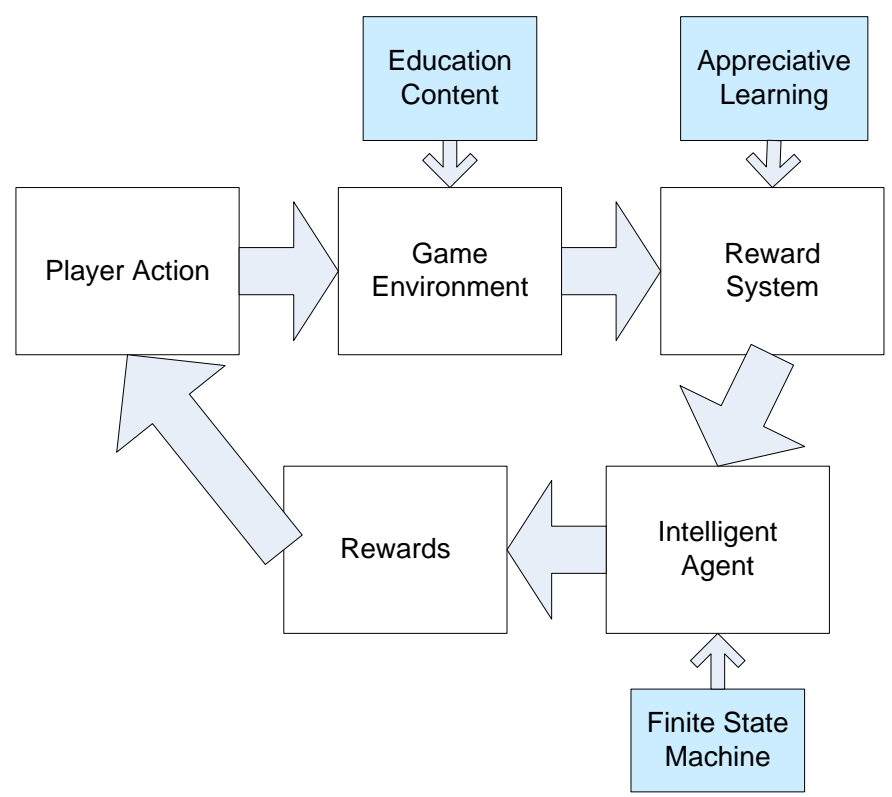

Fig. 1. Overview of the game reward model

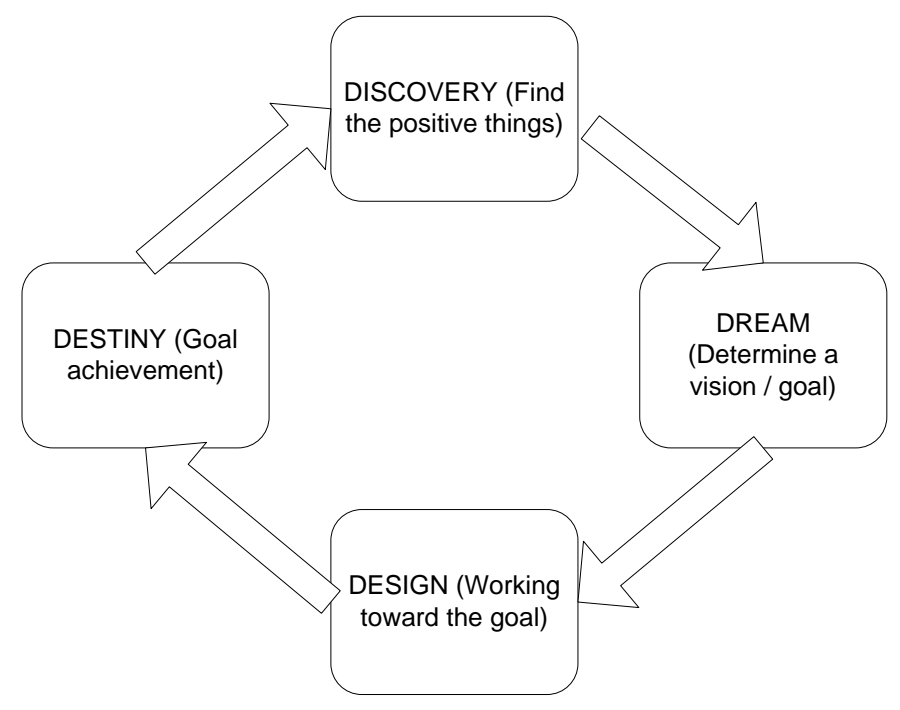

Fig. 2. Appreciative Learning model [22]

The Discovery stage is the discovery of positive things in the learning material. Then after that at the Dream stage, it is followed by the determination of goals based on positive things found. The next stage is Design, which is at this stage learners begin to design things that are their goals. Then the last stage is Destiny, where at this stage the learner realizes his goal. This activity will continue repeats itself as a cycle. The concept will be used to design the reward system. 
Based on research conducted by [23] and, there are eight forms of reward in games, as shown in Table 1 below.

TABLE I. REWARD FORMS

\begin{tabular}{|c|c|}
\hline Reward Forms & Details \\
\hline Score & $\begin{array}{l}\text { - Use numbers to measure player } \\
\text { performance } \\
\text { - Used mainly for player ranking, } \\
\text { serve as self-assessment and } \\
\text { comparison } \\
\text { - No direct effect to gameplay }\end{array}$ \\
\hline Experience point & $\begin{array}{l}\text { - Get point when doing something } \\
\text { in game, usually beat enemies } \\
\text { - Level up when certain point is } \\
\text { achieved } \\
\text { - Stronger character when level up } \\
\text { - Serve as tools for developable } \\
\text { game character } \\
\text { - Has direct effect to gameplay }\end{array}$ \\
\hline Items & $\begin{array}{l}\text { - Get items when doing something } \\
\text { in the game, usually exploration, } \\
\text { beat enemies, and finish the quest } \\
\text { - Items could be very rare (very } \\
\text { useful and drastically improve } \\
\text { character performance) or just } \\
\text { common items (a little useful and } \\
\text { very easy to get) or could just } \\
\text { serve as decoration or collectible } \\
\text { items. } \\
\text { One of the core rewards in game } \\
\text { design }\end{array}$ \\
\hline Resources & 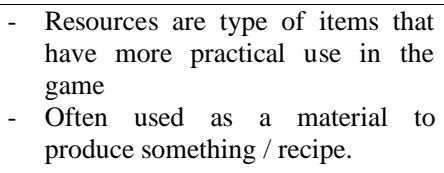 \\
\hline Achievement title & $\begin{array}{l}\text { - Titles that are bounds to player } \\
\text { character or account } \\
\text { - Popular for multiplayer game } \\
\text { - Some titles could be very hard to } \\
\text { earn, thus serve as a sense of } \\
\text { achievement for player. }\end{array}$ \\
\hline Feedback messages & $\begin{array}{l}\text { - Used in many fast-paced games as } \\
\text { instant rewards, for example } \\
\text { messages for number of hits } \\
\text { combo in fighting or rhythm game. } \\
\text { - Could be used as gameplay } \\
\text { tutorial } \\
\text { - Some games use dramatic voice to } \\
\text { improve the messages effect for } \\
\text { player emotion }\end{array}$ \\
\hline Animation and pictures & $\begin{array}{l}\text { - Used mainly in story-based games } \\
\text { - Used as cutscene following } \\
\text { important events in game. }\end{array}$ \\
\hline Unlocking mechanism & $\begin{array}{l}\text { - Giving access to the limited game } \\
\text { content such as area, } \\
\text { items/treasure, level, character. } \\
\text { - Have certain requirements. }\end{array}$ \\
\hline
\end{tabular}

The classification of rewards in the Appreciative Learning stage can be seen in Table 2 below.

TABLE II. REWARD CLASSIFICATION BASED ON APPRECIATIVE LEARNING STAGES

\begin{tabular}{|c|c|c|}
\hline $\begin{array}{c}\text { Appreciative } \\
\text { Learning } \\
\text { stages }\end{array}$ & Main activity & Reward forms \\
\hline Discovery & Exploration & $\begin{array}{ll}\text { - } & \text { Items } \\
\text { - } & \text { Feedback messages } \\
\text { - } & \text { Unlocking } \\
& \text { mechanism }\end{array}$ \\
\hline Dream & $\begin{array}{l}\text { - Choice } \\
\text { - Vision/goals } \\
\text { formulation }\end{array}$ & $\begin{array}{ll}\text { - } & \text { Feedback messages } \\
\text { - } & \text { Animation and } \\
\text { pictures } \\
\text { - Experience point }\end{array}$ \\
\hline Design & $\begin{array}{l}\text { - Collecting } \\
\text { material/resour } \\
\text { ces } \\
\text { - Crafting } \\
\text { - Finishing quest }\end{array}$ & $\begin{array}{ll}\text { - } & \text { Resources } \\
\text { - } & \text { Experience point }\end{array}$ \\
\hline Destiny & $\begin{array}{l}\text { - Appreciation / } \\
\text { acknowledge } \\
\text { ment }\end{array}$ & $\begin{array}{ll}\text { - } & \text { Achievement titles } \\
\text { - } & \text { Feedback messages } \\
\text { - } & \text { Animation and } \\
& \text { pictures }\end{array}$ \\
\hline
\end{tabular}

\section{Reward System to Produce Immersive Elements}

The immersive experiences divided into three, namely sensory immersion, imaginative immersion and challengebased immersion as shown in Figure 3 below [5].

Based on Appreciative Learning reward classification in Table II and type of immersion in Figure 3, we could formulate the possible immersion produced from each stages of Appreciative Learning, as shown in Table III.

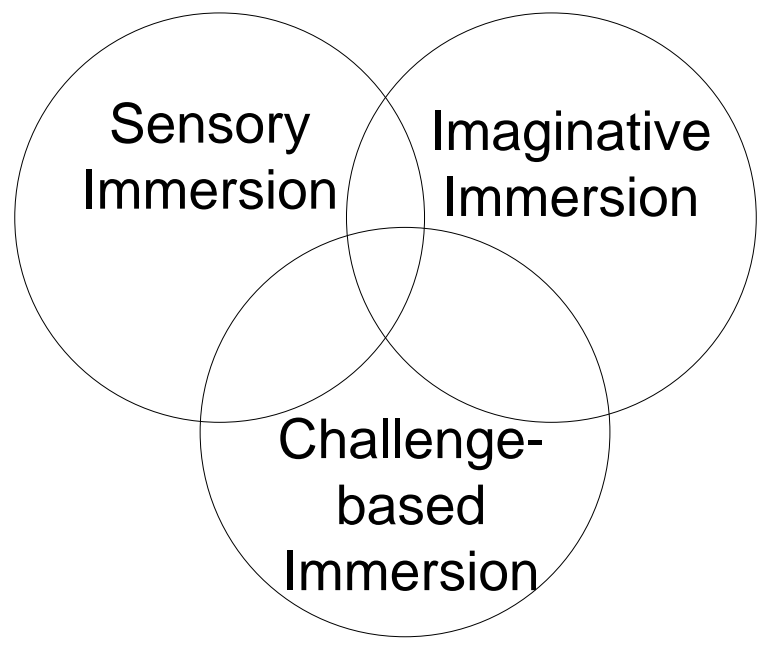

Fig. 3. Type of immersion [5] 
TABLE III. TYPE OF IMMERSION PRODUCED BY EACH STAGES OF APPRECIATIVE LEARNING REWARD SYSTEM

\begin{tabular}{|c|c|c|c|}
\hline $\begin{array}{c}\text { Appreciative } \\
\text { Learning } \\
\text { stages }\end{array}$ & Main activity & Reward forms & $\begin{array}{c}\text { Type of } \\
\text { immersion }\end{array}$ \\
\hline Discovery & Exploration & $\begin{array}{ll}\text { - } & \text { Score } \\
\text { - } & \text { Items } \\
\text { - } & \text { Feedback } \\
& \text { messages } \\
\text { - } & \text { Unlocking } \\
& \text { mechanism }\end{array}$ & $\begin{array}{ll}\text { - } & \text { Challenge- } \\
\text { based } \\
\text { - } & \text { Imaginative }\end{array}$ \\
\hline Dream & $\begin{array}{l}\text { - Choice } \\
\text { - Vision/goals } \\
\text { formulation }\end{array}$ & $\begin{array}{ll}\text { - } & \text { Feedback } \\
& \text { messages } \\
\text { - } & \text { Animation } \\
& \text { and pictures } \\
\text { - } & \text { Experience } \\
\text { point }\end{array}$ & $\begin{array}{ll}- & \text { Sensory } \\
\text { - } & \text { Imaginative }\end{array}$ \\
\hline Design & $\begin{array}{l}\text { - Collecting } \\
\text { material/reso } \\
\text { urces } \\
\text { - Crafting } \\
\text { - Finishing } \\
\text { quest } \\
\end{array}$ & $\begin{array}{ll}\text { - } & \text { Resources } \\
\text { - } & \text { Experience } \\
& \text { point }\end{array}$ & $\begin{array}{l}\text { - Challenge- } \\
\text { based }\end{array}$ \\
\hline Destiny & $\begin{array}{l}\text { - Appreciatio } \\
\mathrm{n} \\
\text { acknowledg } \\
\text { ement }\end{array}$ & $\begin{array}{ll}\text { - } & \text { Achievemen } \\
& \mathrm{t} \text { titles } \\
\text { - } & \text { Feedback } \\
& \text { messages } \\
\text { - } & \text { Animation } \\
& \text { and pictures }\end{array}$ & $\begin{array}{ll}- & \text { Sensory } \\
\text { - } & \text { Imaginative }\end{array}$ \\
\hline
\end{tabular}

\section{Intelligent agent for reward system behaviour}

Finite state machine provides the dynamic behavior of the reward system as shown in Figure 4.

Figure 4 shows that if the certain conditions are met, discovery reward can turn into a dream and vice versa, dream to design and vice versa, design to destiny and vice versa, from destiny can change to discovery but from discovery it cannot be immediately destiny. This adaptive system manages the transition of reward system.

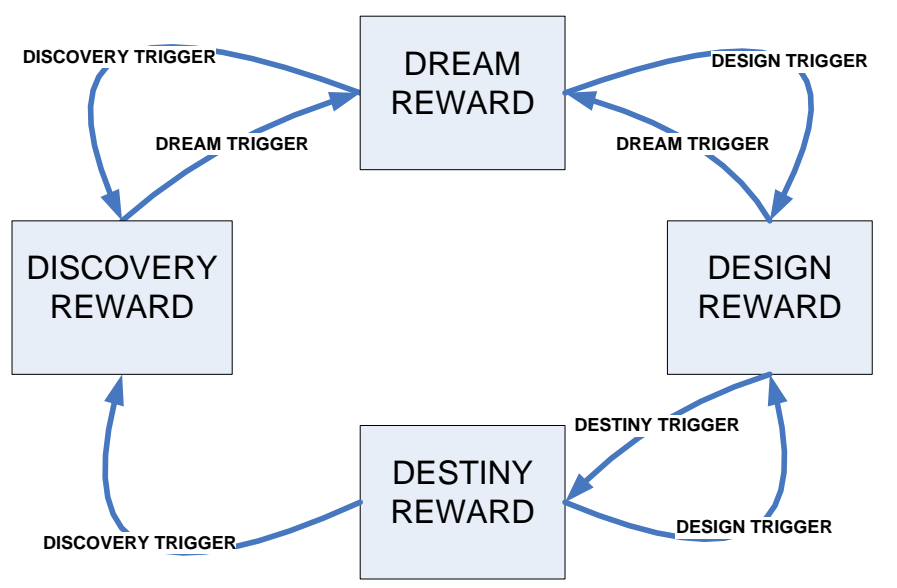

Fig. 4. Overall design of reward system
The overall design of reward system provides general framework and will be implemented specifically within each serious game context.

\section{RESUlT AND DISCUSSION}

We have developed simple education game prototype to implement the reward system. The game is about entrepreneurship education, with Role Playing Game (RPG) genre. The RPG genre was chosen because it offers a balanced practical and cognitive experience, so it's appropriate to use as a learning medium that emphasizes cognitive aspects [2]. Entrepreneurial material for universities will be the content of this educational game. The material generally includes communication, cooperation, investment, innovation, types of business, business challenges, marketing, and business development [24]. The game will follow the main character adventure as a merchant. Here, main character would discover the opportunity for a business at every place visited. The gameplay cycle is discovered the product idea, choose the idea, develop the product, and sell it. The types of rewards used in this game are shown in Table IV.

TABLE IV. TYPE OF REWARDS FOR THE PROTOTYPE

\begin{tabular}{|c|c|c|c|}
\hline $\begin{array}{c}\text { Appreciative } \\
\text { Learning } \\
\text { stages }\end{array}$ & Main activity & $\begin{array}{c}\text { Education } \\
\text { content }\end{array}$ & Reward forms \\
\hline Discovery & $\begin{array}{l}\text { Exploration } \\
\text { (explore town, } \\
\text { unknown area, } \\
\text { talk to NPC) }\end{array}$ & $\begin{array}{ll}\text { - } & \text { Communicat } \\
& \text { ion } \\
\text { - } & \text { Cooperation }\end{array}$ & $\begin{array}{lr}\text { - } & \text { Items key } \\
\text { items to } \\
\text { advance the } \\
\text { main story, } \\
\text { such as product } \\
\text { idea) } \\
\text { - Feedback } \\
\text { messages (hint } \\
\text { from NPC) } \\
\text { - Unlocking } \\
\text { mechanism } \\
\text { (area, maps) }\end{array}$ \\
\hline Dream & $\begin{array}{l}\text { - Choice (by } \\
\text { answering } \\
\text { question from } \\
\text { NPC, get } \\
\text { certain items) } \\
\text { - Vision/goals } \\
\text { formulation } \\
\text { (will be } \\
\text { determined by } \\
\text { player choice } \\
\text { and finishing } \\
\text { quest) }\end{array}$ & $\begin{array}{ll}\text { - } & \text { Investment } \\
\text { - } & \text { Cooperation } \\
\text { - } & \text { Types of } \\
& \text { business } \\
\text { - } & \text { Business } \\
& \text { challenges }\end{array}$ & $\begin{array}{l}\text { - Feedback } \\
\text { messages } \\
\text { (choice } \\
\text { validation) } \\
\text { - Animation and } \\
\text { pictures (game } \\
\text { event) }\end{array}$ \\
\hline Design & $\begin{array}{l}\text { - Collecting } \\
\text { material/resour } \\
\text { ces } \\
\text { - Crafting } \\
\text { product } \\
\text { - Finishing quest }\end{array}$ & $\begin{array}{ll}\text { - } & \text { Innovation } \\
\text { - } & \text { Creativity } \\
\text { - } & \text { Cooperation } \\
\text { - } & \text { Investment } \\
\text { - } & \text { Business } \\
& \text { challenges } \\
\end{array}$ & $\begin{array}{ll}\text { - } & \text { Resources } \\
\text { - } & \text { Product to sell } \\
\text { - } & \text { Experience } \\
& \text { point }\end{array}$ \\
\hline Destiny & $\begin{array}{l}\text { - Appreciation / } \\
\text { acknowledge } \\
\text { ment }\end{array}$ & $\begin{array}{ll}\text { - } & \text { Marketing } \\
\text { - } & \text { Business } \\
& \text { challenges } \\
- & \text { Busines } \\
& \text { development }\end{array}$ & $\begin{array}{ll}\text { - } & \text { Achievement } \\
\text { titles } \\
\text { (successful } \\
\text { entrepreneur) } \\
\text { - Money }\end{array}$ \\
\hline
\end{tabular}




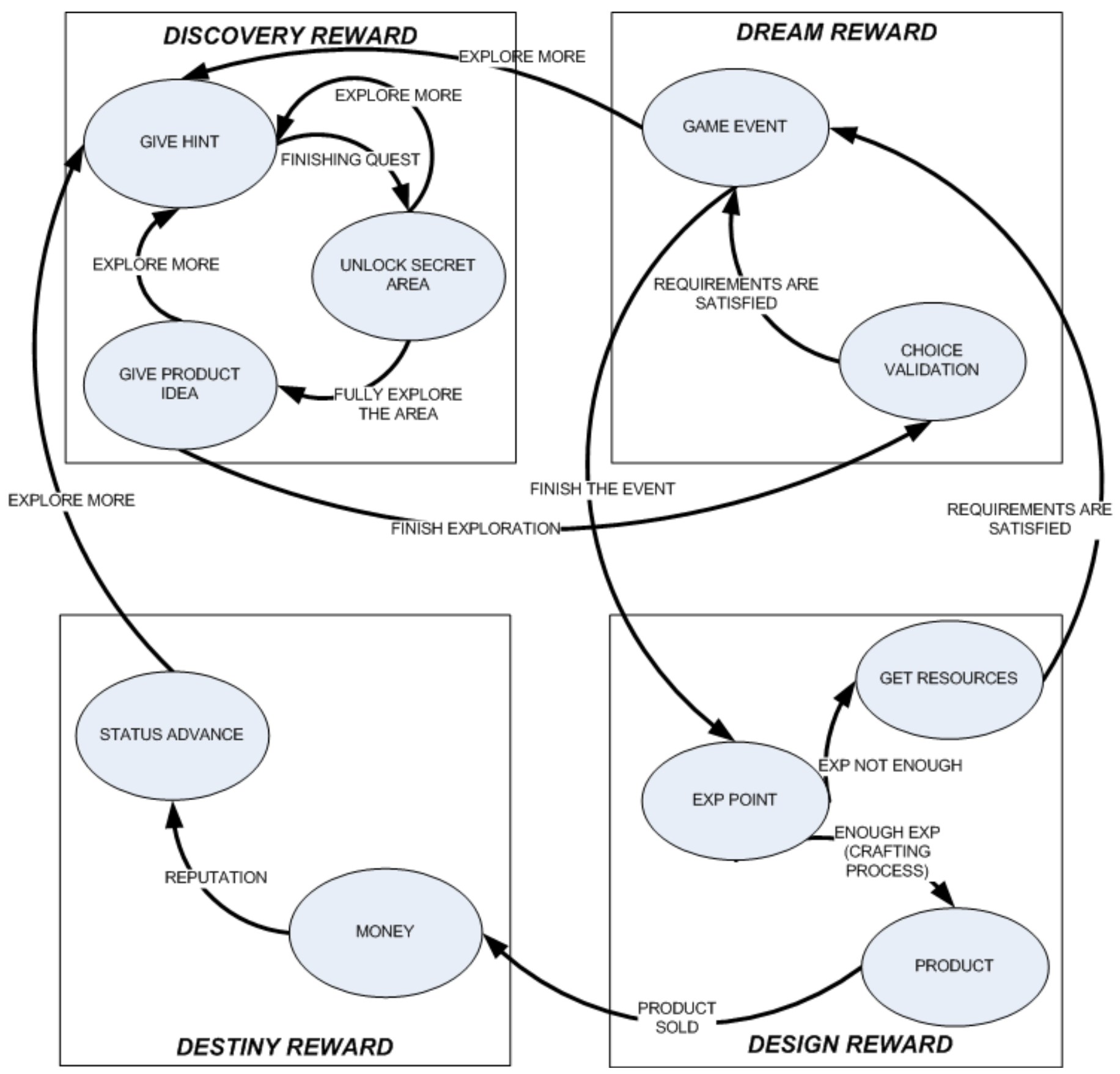

Fig. 5. Reward system design for entrepreneurship serious game

Based on overall reward system in Figure 4, the game uses four stages of Appreciative Learning to design the reward system. The design of reward system based on Appreciative Learning for the game is shown in Figure 5.

Start with the hint, the discovery reward focused on the exploration, where the player will unlock new area, explore it and get the product idea. The product idea reward serves as the transition to dream reward, specifically, choice validation reward. Choice validation will determine the product that will be built by the player, led to game event. Game event will provide player with story, as cutscene, consists of picture and animation for the story. If the player wants to explore more than the reward system will move back to discovery reward. If the player finishes the event and choose not to explore more then it will move to design reward, give the experience point for the player. When there are still EXPs to collect, player will get the resources and trigger the game event in dream reward. Eventually, the EXP requirement will be satisfied, and player will be able to craft the product and sold it, get the money, and led to destiny reward. Besides money, player will get status advance that enable more hint for more exploration and trigger the discovery reward.

Based on Table III, the reward system will produce the immersive experiences that could be classified as sensory, 
imaginative, and challenge-based immersion, as shown in Table V.

TABLE V. TyPE OF IMMERSION PRODUCED By THE REWARD SySTEM

\begin{tabular}{|c|c|c|c|}
\hline $\begin{array}{c}\text { Appreciative } \\
\text { Learning } \\
\text { stages }\end{array}$ & Main activity & Reward forms & $\begin{array}{c}\text { Type of } \\
\text { immersion }\end{array}$ \\
\hline Discovery & $\begin{array}{l}\text { Exploration } \\
\text { (explore town, } \\
\text { unknown area, } \\
\text { talk to NPC) }\end{array}$ & 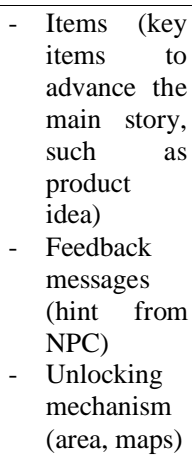 & $\begin{array}{ll}\text { - } & \text { Challenge- } \\
\text { based } \\
\text { - } & \text { Imaginative }\end{array}$ \\
\hline Dream & $\begin{array}{l}\text { - Choice (by } \\
\text { answering } \\
\text { question } \\
\text { from NPC, } \\
\text { get certain } \\
\text { items) } \\
\text { - Vision/goals } \\
\text { formulation } \\
\text { (will be } \\
\text { determined } \\
\text { by player } \\
\text { choice and } \\
\text { finishing } \\
\text { quest) }\end{array}$ & $\begin{array}{l}\text { - Feedback } \\
\text { messages } \\
\text { (choice } \\
\text { validation) } \\
\text { - Animation } \\
\text { and pictures } \\
\text { (game } \\
\text { event) }\end{array}$ & $\begin{array}{ll}- & \text { Sensory } \\
- & \text { Imaginative }\end{array}$ \\
\hline Design & $\begin{array}{l}\text { - Collecting } \\
\text { material/reso } \\
\text { urces } \\
\text { - Crafting } \\
\text { product } \\
\text { - Finishing } \\
\text { quest } \\
\end{array}$ & $\begin{array}{ll}\text { - } & \text { Resources } \\
\text { - } & \text { Product to } \\
\text { sell } \\
\text { - } & \text { Experience } \\
\text { point }\end{array}$ & $\begin{array}{l}\text { - } \begin{array}{l}\text { Challenge- } \\
\text { based }\end{array}\end{array}$ \\
\hline Destiny & $\begin{array}{l}\text { - Appreciatio } \\
\mathrm{n} \\
\text { acknowledg } \\
\text { ement }\end{array}$ & $\begin{array}{ll}\text { - } & \text { Achievemen } \\
\mathrm{t} \text { titles } \\
\text { (successful } \\
\text { entrepreneur } \\
\text { - Money } \\
\text { - Mon }\end{array}$ & $\begin{array}{ll}- & \text { Sensory } \\
\text { - } & \text { Imaginative }\end{array}$ \\
\hline
\end{tabular}

We use the modified version of Game Experience Questionnaire [25] to get the user experience for this game. We design the qualitative interview questions as shown in Table VI.

TABLE VI. LIST OF INTERVIEW QUESTIONS

\begin{tabular}{|c|l|c|}
\hline No & \multicolumn{1}{|c|}{ Questions } & \multicolumn{1}{|c|}{$\begin{array}{c}\text { Immersion } \\
\text { Types }\end{array}$} \\
\hline 1 & $\begin{array}{l}\text { Describe your feeling when exploring a new area in } \\
\text { the game }\end{array}$ & \multirow{2}{*}{ Imaginative } \\
\hline 2 & What do you feel when interacting with NPC? & \\
\hline 3 & What drives you to examine objects in the game? & \\
\hline 4 & What do you feel when you found the objectives? & \\
\hline 5 & What motivate you when choosing objectives? & \\
\hline 6 & What motivate you to win the battle? & \multirow{2}{*}{$\begin{array}{c}\text { Challenge- } \\
\text { based }\end{array}$} \\
\hline 7 & What motivate you to gather the resources? & \multicolumn{1}{|c}{} \\
\hline 8 & $\begin{array}{l}\text { What influence does the game difficulty given to } \\
\text { you? }\end{array}$ &
\end{tabular}

\begin{tabular}{|c|l|l|}
\hline 9 & Describe your feeling when completing an objective & \\
\hline 10 & What do you feel after you finished the dungeon? & \\
\hline 11 & Do you like the cutscene? & \multirow{2}{*}{ Sensory } \\
\hline 12 & Do you interested in the main character? & \\
\hline 13 & Do you enjoy the game world design? & \\
\hline
\end{tabular}

For the evaluation, experienced gamers, people who have minimum experience in playing games and teachers are recruited to play the games and answer the questions. The results summary are shown in Table VII.

TABLE VII. INTERVIEW RESULTS SUMMARY

\begin{tabular}{|c|c|c|c|c|}
\hline \multirow[t]{2}{*}{ Respondents } & \multicolumn{4}{|c|}{ Responses Summary } \\
\hline & Imaginative & $\begin{array}{c}\text { Challenge- } \\
\text { based }\end{array}$ & Sensory & Overall \\
\hline $\begin{array}{l}\text { Experienced } \\
\text { gamer }\end{array}$ & $\begin{array}{l}\text { Excited to } \\
\text { find new } \\
\text { area / items, } \\
\text { expect more } \\
\text { objectives } \\
\text { /product } \\
\text { ideas }\end{array}$ & $\begin{array}{l}\text { Sometimes } \\
\text { feels the } \\
\text { battle are } \\
\text { too } \\
\text { repetitive, } \\
\text { below } \\
\text { average } \\
\text { motivation } \\
\text { because too } \\
\text { easy and } \\
\text { predictable }\end{array}$ & $\begin{array}{l}\text { Average } \\
\text { feelings for } \\
\text { the game } \\
\text { world and } \\
\text { character, } \\
\text { the main } \\
\text { character } \\
\text { should be } \\
\text { more } \\
\text { recognizable }\end{array}$ & $\begin{array}{l}\text { Feels the } \\
\text { game good } \\
\text { enough, } \\
\text { have high } \\
\text { expectation } \\
\text { because of } \\
\text { the } \\
\text { experience } \\
\text { in playing } \\
\text { commercial } \\
\text { games }\end{array}$ \\
\hline Non-gamer & $\begin{array}{l}\text { Excited to } \\
\text { find new } \\
\text { area / items, } \\
\text { interested to } \\
\text { find more } \\
\text { secret stuff }\end{array}$ & $\begin{array}{l}\text { Motivated } \\
\text { in doing the } \\
\text { battle, tends } \\
\text { to lose in } \\
\text { battle and } \\
\text { feels the } \\
\text { game too } \\
\text { difficult, } \\
\text { but after } \\
\text { several } \\
\text { attempts } \\
\text { found that } \\
\text { the game } \\
\text { difficulty is } \\
\text { enjoyable }\end{array}$ & $\begin{array}{l}\text { Feels } \\
\text { excited in } \\
\text { game world, } \\
\text { have overall } \\
\text { good } \\
\text { opinion for } \\
\text { the main } \\
\text { character }\end{array}$ & $\begin{array}{l}\text { Immersed } \\
\text { in the game, } \\
\text { sometimes } \\
\text { feels the } \\
\text { challenge is } \\
\text { too } \\
\text { difficult, } \\
\text { curious } \\
\text { enough to } \\
\text { do } \\
\text { something } \\
\text { new }\end{array}$ \\
\hline Teacher & $\begin{array}{l}\text { Excited to } \\
\text { find new } \\
\text { area / items, } \\
\text { interested to } \\
\text { find more } \\
\text { secret stuff }\end{array}$ & $\begin{array}{l}\text { Not too } \\
\text { motivated } \\
\text { in doing the } \\
\text { battle and } \\
\text { tends to end } \\
\text { it quickly, } \\
\text { but } \\
\text { motivated } \\
\text { enough to } \\
\text { gather the } \\
\text { resources } \\
\text { and found } \\
\text { satisfaction } \\
\text { in } \\
\text { completing } \\
\text { the } \\
\text { objectives }\end{array}$ & $\begin{array}{l}\text { Feels } \\
\text { excited in } \\
\text { game world, } \\
\text { have overall } \\
\text { good } \\
\text { opinion for } \\
\text { the main } \\
\text { character }\end{array}$ & $\begin{array}{l}\text { Immersed } \\
\text { enough in } \\
\text { the game, } \\
\text { not too } \\
\text { interested in } \\
\text { the } \\
\text { challenge }\end{array}$ \\
\hline
\end{tabular}

Overall, the result shows that the user was immersed enough in the game activities. The experienced gamer has no problem in playing the game but has a high standard regarding the game. The non-gamer user has several difficulties in challenge-based activities and feels the game too difficult. But overall feels immersed in the game and motivated by the challenge they faced. The teacher feels engaged in the 
imaginative-based activities but feels irrelevant when coming to challenge-based activities and feels there should be more education contents.

\section{CONCLUSION}

The immersive reward system could be developed using Appreciative Learning to fulfill immersive measurement of the game. The experienced gamer, who has played many commercial games seems to be bored sometimes and expect more from the game. We find that the non-gamer was the one that gets the most out of this model, although seems to have a steeper learning curve in completing the objectives. The lecturer found that some activities irrelevant to the learning material. Overall, the model could provide the immersive experiences in learning using educational games.

\section{REFERENCES}

[1] M. Simkova, "Using of Computer Games in Supporting Education," Procedia - Soc. Behav. Sci., vol. 141, pp. 1224-1227, 2014.

[2] M. Vinogradova and N. Ivanova, "Pedagogical Conditions for RolePlaying Game Development in Senior Preschool Age Children," Procedia - Soc. Behav. Sci., vol. 233, no. May, pp. 297-301, 2016.

[3] C. V. Zalka, "Adventures in the Classroom Creating Role-Playing Games Based on Traditional Stories for the High School Curriculum," East Tennessee State University, 2012.

[4] M. B. Carvalho et al., "An activity theory-based model for serious games analysis and conceptual design," Comput. Educ., vol. 87, pp. 166-181, 2015.

[5] L. Ermi and F. Mäyrä, "Fundamental Components of the Gameplay Experience: Analysing Immersion," in Changing Views: Worlds in Play, 2005, pp. 15-27.

[6] J. F. Micallef, "Illusion Master: Extending Self-Presence and Challenging Immersion in and through Digital Games," $G|A| M \mid E$ Games as Art, Media, Entertain., vol. 1, no. 5, pp. 1-6, 2016.

[7] M. Rietzler, K. Plaumann, T. Kränzle, M. Erath, A. Stahl, and E. Rukzio, "VaiR: Simulating 3D Airflows in Virtual Reality," Proc. 2017 CHI Conf. Hum. Factors Comput. Syst., pp. 5669-5677, 2017.

[8] F. Pour Rahimian, T. Arciszewski, and J. S. Goulding, "Successful education for AEC professionals: case study of applying immersive game-like virtual reality interfaces," Vis. Eng., vol. 2, no. 1, pp. 112, 2014.

[9] Y. Pulijala, M. Ma, M. Pears, D. Peebles, and A. Ayoub, "Effectiveness of Immersive Virtual Reality in Surgical Training-A Randomized Control Trial,” J. Oral Maxillofac. Surg., 2017.

[10] R. Lopes and R. Bidarra, "Adaptivity challenges in games and simulations: A survey," IEEE Trans. Comput. Intell. AI Games, vol. 3, no. 2, pp. 85-99, 2011.

[11] K. Kiili, S. De Freitas, S. Arnab, and T. Lainema, "The design principles for flow experience in educational games," in Procedia Computer Science, 2012

[12] A. Gazzard, "Unlocking the Gameworld: The Rewards of Space and Time in Videogames," Game Stud., vol. 11, no. 1, 2011.

[13] H. Haryanto, "Reward Dinamis dalam Skenario Adaptif Menggunakan Metode Finite State Machine pada Game Edukasi Dynamic Reward in Adaptive Scenario Using Finite State Machine for Education Game," J. Appl. Intell. Syst., vol. 1, no. 2, pp. 144153, 2016.

[14] H. Haryanto, A. Kardianawati, and U. Rosyidah, "Agen Cerdas Untuk Perilaku Reward Appreciative Learning Dalam Game Pendidikan Kewirausahaan," Techno.COM, vol. 16, no. 3, pp. 325336, 2017.

[15] H. Haryanto, R. Haryanto, and Sugiyanto, "Action Recognition System Using Finite State Machine for Support of Adaptive Reward System in an Elementary Student Education Game," in Sustainable Design in Creative Industry Towards Better Human Life International Conference on Creative Industry 2011, 2011.

[16] É. Lavoué, B. Monterrat, M. Desmarais, and S. George, "Adaptive Gamification for Learning Environments," IEEE Trans. Learn. Technol., p. 1, 2018.

[17] C. López and C. Tucker, "Towards Personalized Adaptive Gamification: A Machine Learning Model for Predicting Performance," IEEE Trans. Games, 2018.

[18] G. F. Tondello and R. Orji, "Recommender Systems for Personalized Gamification," in UMAP '17: Adjunct Publication of the 25th Conference on User Modeling, Adaptation and Personalization, 2017, pp. 425-430.

[19] Y. L. Eow, W. A. W. Zah, M. Rosnaini, and B. Roselan, "Appreciative Learning Approach: A New Pedagogical Option," Proc. 18th Int. Conf. Comput. Educ., pp. 607-614, 2010.

[20] A. Mathrani, S. Christian, and A. Ponder-Sutton, "PlayIT: Game based learning approach for teaching programming concepts," Educ. Technol. Soc., vol. 19, no. 5, pp. 5-17, 2016.

[21] R. Assundani and L. Kilbourne, "Enabling entrepreneurial minds: Using appreciative inquiry as a pedagogical tool for uncovering self- awareness and for generating constructivist learning.," $J$. Entrep. Educ., vol. 17, no. 2, pp. 52-62, 2014.

[22] M. Browning, "Appreciative inquiry as a model for assessing the value of business schoold education," J. Bus. Educ. Leadersh., vol. 5, no. 1, pp. 64-70, 2014.

[23] C. Phillips, D. Johnson, and P. Wyeth, "Videogame reward types," ACM Int. Conf. Proceeding Ser., no. October 2017, pp. 103-106, 2013.

[24] I. Mayer, R. Kortmann, I. Wenzler, Á. Wetters, and J. Spaans, "Game-Based Entrepreneurship Education: Identifying Enterprising Personality, Motivation and Intentions Amongst Engineering Students," J. Entrep. Educ., vol. 17, no. 2, pp. 217-245, 2014.

[25] K. Poels, Y. A. W. de Kort, and W. A. IJsselsteijn, "The Game Experience Questionnaire,”Eindhoven, 2013. 